\title{
Estimating the reduction of the firing temperature produced by the addition of energetic fluxes in porcelain tiles through the Fluegel's model
}

\section{(Estimativa da redução da temperatura de queima de porcelanatos com adição de fundentes enérgicos através do uso do modelo de Fluegel)}

\author{
F. Contartesi ${ }^{1 *}$, F. G. Melchiades ${ }^{1,2}, A . O$. Boschi $^{1}$ \\ ${ }^{l}$ Federal University of São Carlos, Graduate Program in Materials Science and \\ Engineering, S. Carlos, SP, Brazil \\ ${ }^{2}$ Centro de Revestimentos Cerâmicos, S. Carlos, SP, Brazil
}

\begin{abstract}
Reducing the firing temperature and accelerating the densification process bring economic and environmental benefits. This study used Fluegel's viscosity model, developed for glasses, to estimate the decrease of the firing temperature produced by the introduction of energetic fluxes in a porcelain body. The experimental results confirmed the prediction of the model, a $30{ }^{\circ} \mathrm{C}$ reduction in the temperature, for the addition of wollastonite. However, for the addition of spodumene, the reduction was slightly higher than the predicted. These results suggested that Fluegel's model may be used to estimate the effects of the introduction of energetic fluxes in porcelain tile compositions. However, the predictions should be seen as a general orientation. Among the limitations of the model were the extrapolation of limit values established by the model for the composition and, above all, the initial hypothesis that the chemical composition of the vitreous phase in porcelain tiles is constant.
\end{abstract}

Keywords: porcelain tile, liquid-phase, viscosity, sintering, Fluegel's model.

Resumo

Reduzir a temperatura de queima e acelerar o processo de densificação implicam em benefícios econômicos e ambientais. Este estudo utilizou o modelo de viscosidade de Fluegel, desenvolvido para vidros, para estimar a diminuição da temperatura de queima produzida pela introdução de fundentes enérgicos em porcelanatos. Os resultados experimentais confirmaram a predição do modelo para a adição de wollastonita, uma redução de $30{ }^{\circ} \mathrm{C}$ na temperatura. No entanto, para a adição de espodumênio, a redução foi ligeiramente maior do que a prevista. Estes resultados sugeriram que o modelo de Fluegel pode ser usado para estimar os efeitos da introdução de fundentes enérgicos em composições de porcelanato. No entanto, as previsões devem ser vistas como uma orientação geral. Entre as limitações do modelo estão a extrapolação dos valores limites estabelecidos pelo modelo para a composição e, sobretudo, a hipótese inicial de que a composição química da fase vítrea em porcelanato é constante.

Palavras-chave: porcelanato, fase líquida, viscosidade, sinterização, modelo de Fluegel.

\section{INTRODUCTION}

Fluegel's viscosity model: the Fluegel's model [1] was developed for glasses to predict the complete viscosity curve as a function of temperature, through a statistical approach and based on over 2200 composition-viscosity literature data for different types of silicate glasses. Based on the chemical composition of the glass, the model estimates the temperature required to achieve a certain viscosity (Fig. 1). The literature defines some critical fixed points in glass melt viscosity [2] and, although there are small variations between the definition of which are the most important or the exact value established for each of them, they can be summarized as in Table I [3]. The model calculations are done initially

*fcontartesi@gmail.com

Dhttps://orcid.org/0000-0002-8775-2103 for three fixed values of viscosity, considered as the main points: $\log _{10}(\eta$, Pa.s $)=1.5,6.6(\sim$ Littleton softening point for soda-lime-silica glasses), and 12.0 (close to $\mathrm{T}_{\mathrm{g}}$ ).

Sintering of porcelain tiles: porcelain tiles are fired at high temperatures, usually between 1100 and $1240{ }^{\circ} \mathrm{C}$, and the densification process occurs fundamentally by progressive vitrification and viscous flow of a liquid-phase [4]. Viscous flow sintering is a complex process that occurs in three main stages, each involving various phenomena, which are controlled by different variables. Fluxes play their role mainly in the intermediate stage, where a large amount of liquid-phase, with proper physical properties, is needed. The most important properties are viscosity and surface tension at a high temperature. As surface tension has little variations at the usual firing temperatures, the most relevant property of the liquid-phase is viscosity, which has a strong dependence on both temperature and chemical composition [4]. At high temperature, the fluxes form eutectic liquid 


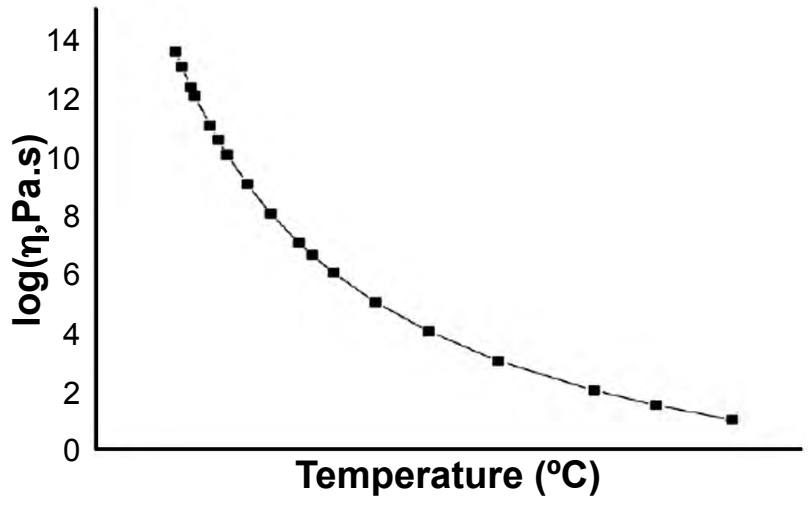

Figure 1: Glass melt viscosity curve model, according to Fluegel's modeling.

[Figura 1: Modelo de curva de viscosidade de vidro, segundo modelamento de Fluegel.]

Table I - Critical points in glass melt viscosity [3].

[Tabela I - Pontos críticos na viscosidade de vidros [3].]

\begin{tabular}{cc}
\hline $\begin{array}{c}\log _{10} \\
\text { (viscosity in Pa.s) }\end{array}$ & Description \\
\hline 1 & Melting point \\
3 & Working point \\
4 & Flow point \\
6.6 & Littleton softening point \\
$8-10$ & Dilatometric softening point $\mathrm{T}_{\mathrm{d}}$ \\
10.5 & Deformation point \\
$11-12.3$ & Glass transition temperature $\mathrm{T}_{\mathrm{g}}$ \\
12 & Annealing point \\
& (stress relieved within a few minutes) \\
13.5 & Strain point \\
& (stress relieved within several hours) \\
\hline
\end{tabular}

that flows through the porous structure of the compact and promotes in the initial stage the rearrangement of the particles [5]. During the permeation of the liquid-phase through the porous compact, the solid particles are partially dissolved into the liquid producing a continuous variation in its chemical composition [6]. The increase in the temperature usually decreases the viscosity of the liquid-phase. The densification rate is therefore affected by three important variables: particle size (geometric factor), viscosity (kinetic factor), and surface tension (thermodynamic factor), according to [5]:

$$
\frac{\Delta \mathrm{V}}{\mathrm{V}_{0}}=\frac{3 \Delta \mathrm{L}}{\mathrm{L}_{0}}=\frac{9 \gamma}{4 \eta \mathrm{r}} \mathrm{t}
$$

where $\mathrm{V}$ is volume, $\mathrm{L}$ is the length, $\gamma$ is the surface tension, $\eta$ is the viscosity, $r$ is the radius of particle and $t$ is time. The introduction of energetic fluxes usually produces liquid-phases with lower viscosity at a lower temperature, accelerating the densification process. However, these properties may increase the tendency to pyroplastic deformation.

Regarding the possibility of reducing the firing temperature and accelerating the densification process, that would bring energy-saving and economic and environmental advantages, it is quite interesting to be able to estimate the benefits provided by different fluxes. To achieve this and assuming that composition of the melt remains unchanged upon cooling, the objective of the present study was to verify the possibility of using the Fluegel's model to estimate the firing temperature reduction provided by different fluxes.

\section{MATERIALS AND METHODS}

Based on the literature [7-12], wollastonite and spodumene were chosen as the energetic fluxes that were introduced in a standard composition (STD). The effects of these additions were estimated through the Fluegel's model [1] and the predictions were compared with the experimental results. The detailed methodology is schematically presented in Fig. 2.

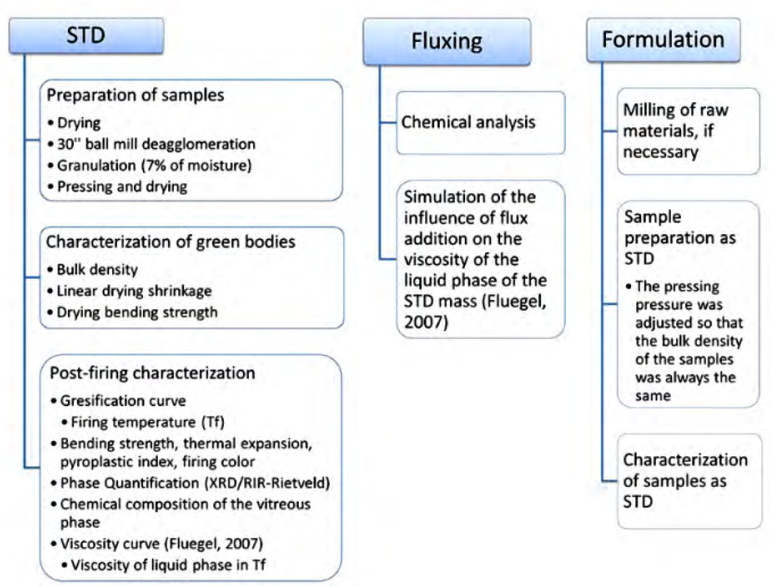

Figure 2: Methodology presented in three sequential steps. [Figura 2: Metodologia apresentada em três etapas sequenciais.]

Standard composition: an industrial spray dried powder, used to produce glazed porcelain tiles was the standard (STD). It was used to comparatively evaluate the effects of the addition of the fluxes. Initially, the characteristics of STD powder, before and during firing, were evaluated as follows: i) complete drying at $110{ }^{\circ} \mathrm{C}$; ii) de-agglomeration of the granules, necessary for comparison purpose, because the introduction of the fluxes into the granulated powder would not result in a homogeneous distribution; iii) humidification and granulation: the mass was humidified with $7 \%$ water and granulated in sieve, according to laboratory procedure; iv) pressing: the samples were uniaxially pressed in a Nannetti automatic press with a size of $6.0 \times 2.0 \times 0.5 \mathrm{~cm}$ and a pressing pressure of $380 \mathrm{kgf} / \mathrm{cm}^{2} ; \mathrm{v}$ ) drying the samples at $110{ }^{\circ} \mathrm{C}$ to eliminate the moisture used for forming; vi) measurements of bulk density: the geometric volume was determined with the aid of a digital caliper with an accuracy of $0.01 \mathrm{~mm}$; the linear drying shrinkage was measured in the direction of the length of the samples and the flexural strength of the green body through the three-point flexural test in 
Nannetti CC-96-2006 fleximeter; vii) firing: the samples were fired in a laboratory roller kiln at various temperatures; viii) gresification curves: the water absorption of the fired samples was evaluated by immersion in boiling water for $2 \mathrm{~h}$; linear firing shrinkage was measured with a caliper; the gresification curves were then plotted to represent the behavior of the compositions during firing and to determine the reference firing temperature; ix) fired bending strength: the flexural strength of the fired samples was evaluated by the three-point flexural test in Nannetti CC-96-2006 fleximeter; $x$ ) coefficient of linear thermal expansion: the dilatometric analyzes of the fired samples were performed in a BP Eng. dilatometer, RB3000, with samples measuring $50 \times 10 \times 5 \mathrm{~mm}$; the coefficients of thermal expansion $\left(\alpha_{25-325}\right)$ were calculated in the temperature range of 25 to $325^{\circ} \mathrm{C}$, with a heating rate of $5{ }^{\circ} \mathrm{C} / \mathrm{min}$; and xi) pyroplasticity index (PI): the samples $(100 \times 10 \times 5 \mathrm{~mm})$ were pressed with the same pressure conditions described in iv; after drying, the firing was carried out in laboratory roller kiln in standard procedure; the samples, rested on two refractory supports 80 $\mathrm{mm}$ distant from each other, were fired and the pyroplasticity index (PI) was determined by:

$$
\mathrm{PI}=\frac{4 \mathrm{Sh}^{2}}{3 \mathrm{~L}^{4}}
$$

where PI is the pyroplastic index, $\mathrm{S}$ is the maximum deflection, $\mathrm{h}$ is the thickness of the body and $\mathrm{L}$ is the distance between the supports; xii) firing color: colorimetric analyses were performed using a Minolta CM-2600d spectrophotometer and the results obtained through the chromatic coordinates $\mathrm{L}^{*}, \mathrm{a}^{*}$ and $\mathrm{b}^{*}$ of the CIELab system. The $\mathrm{L}^{*}$ coordinate indicates the degree of brightness of the samples, the parameter $\mathrm{a}^{*}$ the degree of red or green and the parameter $b^{*}$ the degree of yellow or blue.

Based on the standard requirement for glazed porcelain tiles [13], water absorption $\leq 0.5 \%$, the temperature at which the compositions reached this value was used to establish the reference firing temperature. The identification of the phases presenting in the samples fired at the reference temperature was done by X-ray diffraction. The quantitative analysis of the phases, including the non-crystalline phase, was done by RIR-Rietveld method, analyzing the intensity of the most intense peak of each phase, relating it to the peak of a phase reference, in this case, corundum. From the chemical and mineralogical analyses of the STD, the chemical composition of the vitreous phases was estimated by subtracting the chemical contribution of each mineralogical phase, considering its stoichiometric formulas, from the total chemistry of the composition, according to the method proposed in [14]. The chemical composition of the vitreous phase was used to estimate its viscosity at the temperatures of interest, through Fluegel's model [1].

Fluxing agents: based on the chemical composition of the fluxing agents, the influence of their addition on the viscosity of the liquid-phase of the standard mass was simulated using Fluegel's modeling. For the sake of simplicity, it was considered that the added raw material completely melted and mixed with the liquid-phase of the basic mass without interfering with its formation. Therefore, for theoretical calculation purposes, the chemical composition of the liquid-phase formed in a composition was the sum of the composition of the liquid-phase in the standard mass and the composition of the flux. The viscosity was assumed to be sufficient to determine the firing temperature. For the addition of $6.5 \%$ wollastonite the viscosity versus temperature curve of the new formulation was estimated by the Fluegel's model. Using the curve of the standard body as a reference, the temperature at which the liquid-phase of the new composition would have the same viscosity was estimated. In this case, the reduction of approximately $30^{\circ} \mathrm{C}$ in temperature was estimated. Subsequently, the amount of spodumene necessary to produce the same reduction in the firing temperature was also calculated. Thus, the formulations were established: i) addition of $6.5 \%$ wollastonite to the standard (Table II), which corresponded to the addition of $2.7 \% \mathrm{CaO}$; and ii) addition of $20 \%$ spodumene, which corresponded to $0.78 \%$ of $\mathrm{Li}_{2} \mathrm{O}$.

Table II - Formulation with the addition of flux.

[Tabela II - Formulações com adição de fundente.]

\begin{tabular}{cccc}
\hline Sample & Fluxing & STD $(\%)$ & Fluxing RM (\%) \\
\hline STD & - & 100 & - \\
W6.5 & Wollastonite & 93.5 & 6.5 \\
E20 & Spodumene & 80.0 & 20.0 \\
\hline
\end{tabular}

Formulations: the fluxes were milled to achieve the same residue on ABNT \#325 sieve (45 $\mu \mathrm{m}$ aperture size) of the STD, to avoid a non-uniform distribution. To assure the comparability of the results, the formulations were prepared and characterized according to the procedure used for the standard composition. The mixture was made in a ball mill for $30 \mathrm{~s}$ in order to disaggregate the granules and mix the fluxes without further milling. The pressing pressure was adjusted so that the bulk density of the samples was always the same.

\section{RESULTS AND DISCUSSION}

Table III presents the phase composition of the STD sample at the reference firing temperature and the corresponding chemical composition of its vitreous phase is shown in Table IV. This table also presents the chemical compositions of the wollastonite, the spodumene and the estimated chemical compositions of the vitreous phases of the formulations W6.5 and E20. The elements responsible for the fluxing action of the wollastonite and the spodumene were calcium and lithium, respectively.

Based on the chemical compositions of the vitreous phases presented in Table IV, Fig. 3 shows the viscosity versus temperature curves according to Fluegel's model. The curves showed that the compositions with the energetic fluxes should result in approximately $30^{\circ} \mathrm{C}$ reduction of the firing temperature. The viscosity at the firing temperature 
Table III - Phase composition of the STD sample fired at the reference firing temperature.

[Tabela III - Composição de fases da amostra STD queimada na temperatura de referência.]

\begin{tabular}{cccc}
\hline Vitreous phase & Quartz & Mullite & Orthoclase \\
\hline 53 & 30 & 12 & 5 \\
\hline
\end{tabular}

( 4.3) corresponded with the critical viscosity assigned in the literature for sintering ( 4-5 $\log _{10}$, Pa.s) $[14,15]$. The results of the characterizations before firing are shown in Table V. To enhance the comparability of the behavior during firing, the pressing pressure was adjusted to produce samples with the same bulk density.

On the gresification curves shown in Fig. 4, the reference firing temperatures, at which the water absorption reached $0.5 \%$ for each composition, are highlighted. The STD composition required a temperature of $1215{ }^{\circ} \mathrm{C}$ to reach the water absorption of $0.5 \%$ while the sample containing $6.5 \%$ of wollastonite required $1185{ }^{\circ} \mathrm{C}$, a reduction of 30 ${ }^{\circ} \mathrm{C}$, as expected. For the composition containing $20.0 \%$ of spodumene, the reduction of the required firing temperature was even higher, $45^{\circ} \mathrm{C}$. The proximity between the firing temperature required to achieve a drop of $30^{\circ} \mathrm{C}$, as estimated by Fluegel's model and that experimentally determined, suggested that, despite all the differences between the basis on which the model is based and the porcelain tile system, the model could be applied with a good accuracy for the wollastonite flux.

Apart from the differences between the glasses on which the model is based and the porcelain tiles, a major obstacle

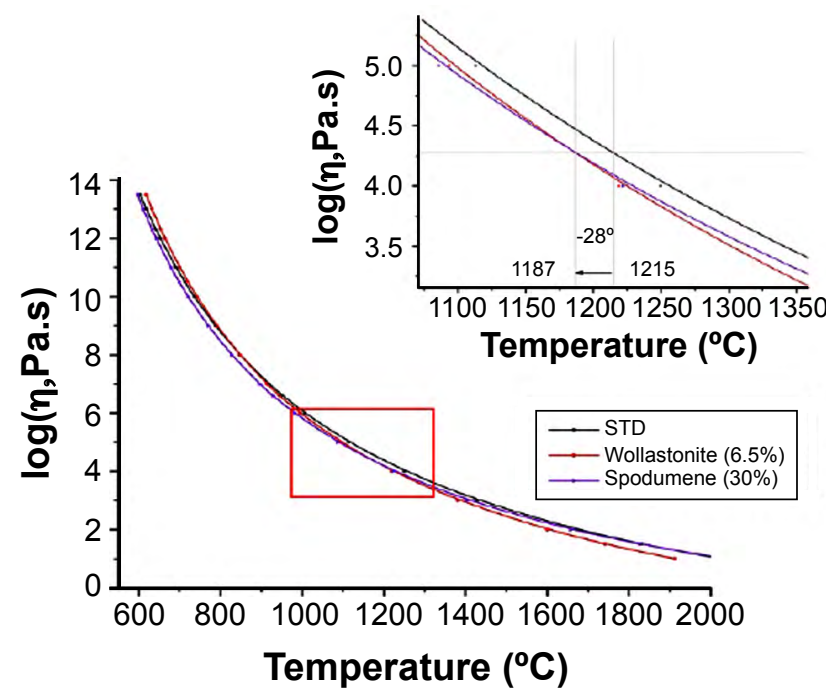

Figure 3: Viscosity curves according to Fluegel's model of the standard and the established fluxing formulations, showing for the same viscosity the expected reduction in firing temperature.

[Figura 3: Curvas de viscosidade segundo o modelo de Fluegel da massa padrão e das formulações estabelecidas, mostrando para uma mesma viscosidade a redução esperada na temperatura de queima.]

for the application of Fluegel's model to the porcelain tiles system is to summarize the variables affecting a complex phenomenon such as viscous flow sintering, or vitrification, to one single variable, the viscosity. Another aspect worth mentioning is the fact that the Fluegel's model has limits of the glass compositions, which were sometimes exceeded in this study, mainly by the amount of $\mathrm{Al}_{2} \mathrm{O}_{3}$ present in the ceramic

Table IV - Chemical composition of the raw materials and estimated chemical compositions of the vitreous phases of STD, W6.5, and E20, fired at the reference firing temperature.

[Tabela IV - Composição química das matérias-primas e composição química estimada da fase vítrea das massas STD, W6.5 e E20, queimadas na temperatura de queima de referência.]

\begin{tabular}{cccccc}
\hline Oxide & STD vitreous phase & Wollastonite & W6.5 vitreous phase & Spudomene & E20 vitreous phase \\
\hline $\mathrm{LOI}$ & - & 5.77 & - & 3.37 & - \\
$\mathrm{SiO}$ & 66.40 & 46.48 & 64.93 & 63.16 & 65.33 \\
$\mathrm{Al}_{2} \mathrm{O}_{3}$ & 17.24 & 0.37 & 16.15 & 27.45 & 19.10 \\
$\mathrm{Na}_{2} \mathrm{O}$ & - & 0.02 & - & 0.18 & 0.03 \\
$\mathrm{~K}_{2} \mathrm{O}$ & 4.87 & 0.08 & 4.56 & 0.14 & 3.92 \\
$\mathrm{MgO}$ & 4.50 & 0.90 & 4.27 & 0.49 & 3.70 \\
$\mathrm{CaO}$ & 0.33 & 45.65 & 3.10 & 0.03 & 0.27 \\
$\mathrm{PbO}$ & 0.02 & - & 0.02 & - & 0.02 \\
$\mathrm{Li} 2 \mathrm{O}$ & - & - & - & 4.04 & 0.78 \\
$\mathrm{ZrO}_{2}$ & 0.46 & - & 0.43 & - & 0.37 \\
$\mathrm{TiO}_{2}$ & 1.89 & 0.01 & 1.76 & 0.05 & 1.52 \\
$\mathrm{Fe}_{2} \mathrm{O}_{3}$ & 4.22 & 0.35 & 3.96 & 0.68 & 3.50 \\
$\mathrm{MnO}_{2}$ & 0.08 & - & 0.07 & 0.01 & 0.06 \\
$\mathrm{P}_{2} \mathrm{O}_{5}$ & 0.02 & 0.10 & 0.02 & 0.04 & 0.02 \\
\hline
\end{tabular}


Table V - Characterization results of the samples before firing.

[Tabela V - Resultados da caracterização das amostras antes da queima.]

\begin{tabular}{cccc}
\hline Property & STD & W6.5 & E20 \\
\hline $\begin{array}{c}\text { Pressing pressure } \\
\left(\mathrm{kgf} / \mathrm{cm}^{2}\right)\end{array}$ & 380 & 360 & 310 \\
$\begin{array}{c}\text { Bulk density } \\
\left(\mathrm{g} / \mathrm{cm}^{3}\right)\end{array}$ & $1.95 \pm 0.01$ & $1.95 \pm 0.01$ & $1.95 \pm 0.01$ \\
$\begin{array}{c}\text { Drying linear } \\
\text { shrinkage } \\
(\%)\end{array}$ & $0.02 \pm 0.01$ & $0.11 \pm 0.01$ & $0.03 \pm 0.01$ \\
$\begin{array}{c}\text { Dry flexural } \\
\text { strength } \\
\left(\mathrm{kgf} / \mathrm{cm}^{2}\right)\end{array}$ & $47 \pm 3$ & $43 \pm 3$ & $35 \pm 3$ \\
\hline
\end{tabular}
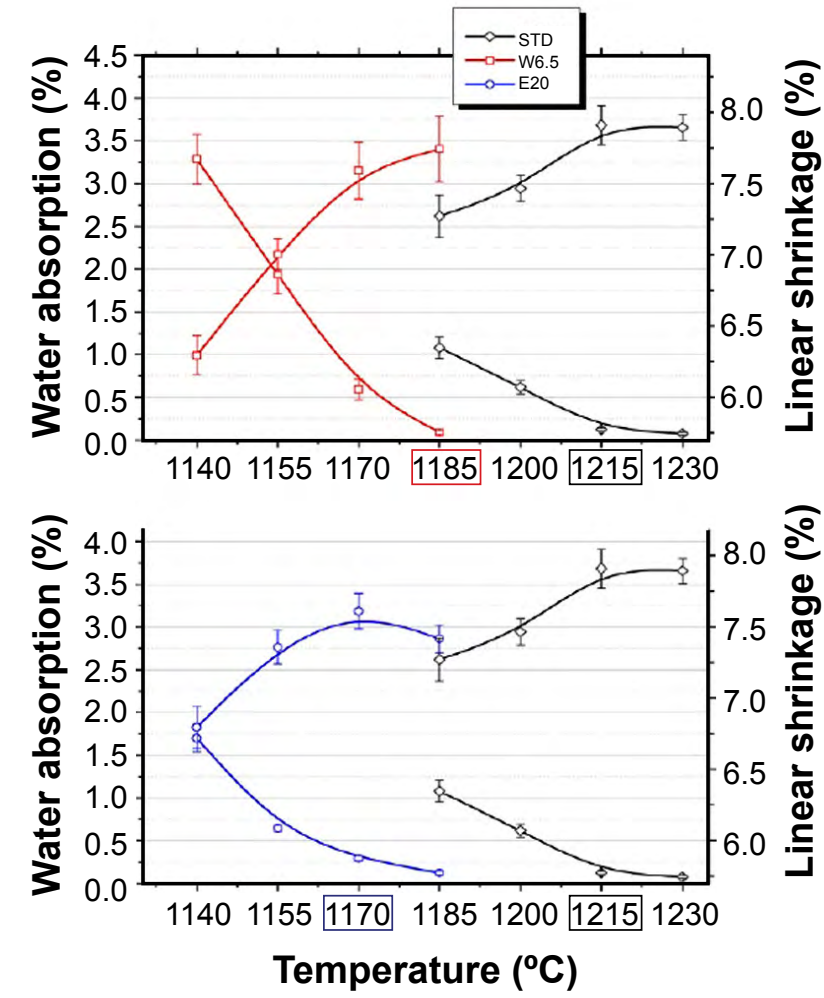

Figure 4: Gresification curves of the STD composition and the compositions containing wollastonite and spodumene. On the temperature axis the reference firing temperature for each composition is highlighted.

[Figura 4: Curvas de gresificação da massa padrão e das formulações contendo wollastonita e espodumênio. No eixo de temperatura, a temperatura de queima de referência para cada composição é destacada.]

tile products. On the other hand, the proximity between the prediction and the experimental result suggested that for the wollastonite addition the composition of the liquid-phase did not change significantly during sintering. However, with respect to the spodumene containing composition, the model's prediction was not so good. As can be seen in Fig. 4,
Table VI - Characterization results of the samples after firing.

[Tabela VI - Resultados da caracterização das amostras depois da queima.]

\begin{tabular}{|c|c|c|c|c|}
\hline \multicolumn{2}{|c|}{ Property } & STD & W6.5 & E20 \\
\hline \multicolumn{2}{|c|}{$\begin{array}{l}\text { Reference firing } \\
\text { temperature }\left({ }^{\circ} \mathrm{C}\right)\end{array}$} & 1215 & 1185 & 1170 \\
\hline \multicolumn{2}{|c|}{ Water absorption (\%) } & $0.1 \pm 0.0$ & $0.1 \pm 0.0$ & $0.3 \pm 0.0$ \\
\hline \multicolumn{2}{|c|}{ Linear shrinkage (\%) } & $7.9 \pm 0.1$ & $7.7 \pm 0.2$ & $7.6 \pm 0.1$ \\
\hline \multicolumn{2}{|c|}{$\begin{array}{l}\text { Fired flexural strength } \\
\text { (MPa) }\end{array}$} & $52 \pm 1$ & $51 \pm 2$ & $34 \pm 3$ \\
\hline \multicolumn{2}{|c|}{ Pyroplastic index $\left(\mathrm{cm}^{-1}\right)$} & $3.5 \times 10^{-5}$ & $4.9 \times 10^{-5}$ & $4.2 \times 10^{-5}$ \\
\hline \multicolumn{2}{|c|}{$\begin{array}{l}\text { Coefficient of thermal } \\
\text { expansion }\left({ }^{\circ} \mathrm{C}^{-1}\right)\end{array}$} & $73.9 \times 10^{-7}$ & $73.9 \times 10^{-7}$ & $64.4 \times 10^{-7}$ \\
\hline \multirow{3}{*}{$\begin{array}{l}\text { Chromatic } \\
\text { coordinate }\end{array}$} & $\mathrm{L}^{*}$ & 54.3 & 52.6 & 55.7 \\
\hline & $a^{*}$ & 1.6 & 3.1 & 4.9 \\
\hline & $b^{*}$ & 11.0 & 12.2 & 13.4 \\
\hline
\end{tabular}

the introduction of spodumene had a stronger fluxing action in comparison with the wollastonite. The Fluegel's model predicted a drop of $30^{\circ} \mathrm{C}$, but experimentally the reference firing temperature was $1170^{\circ} \mathrm{C}$, a drop of $45^{\circ} \mathrm{C}$. The stronger fluxing action of the spodumene can be associated with the introduction of $\mathrm{Li}$ ions into the liquid-phase, resulting in stronger and more complex interactions than the model was able to predict.

In general, alkaline oxides act as glass network modifiers breaking Si-O-Si linkages. This generates nonbridging oxygen in the network, where reticular points of discontinuity are located, which weakens cohesion and leads to a decrease in viscosity [2]. In addition, the radius and the field strength (ratio of charge to radius) of cations are also associated with the influence they exert on the viscosity $[16,17]$. Under the same conditions, the viscosity decreases with the decrease of the ionic radius. So, the viscosity of the glass decreases in the following order: $\mathrm{K}^{+}>\mathrm{Na}^{+}>\mathrm{Li}^{+}$. Thus $\mathrm{Li}$, with its small ionic radius and high diffusion coefficient, can modify the properties of the vitreous phase more quickly than other ions such as $\mathrm{K}$ and $\mathrm{Na}$ and produces the largest viscosity reduction. The alkaline earth oxides, such as $\mathrm{Ca}$ in wollastonite, also act as modifiers, weakening the glass network. But because of the double charge, their effect tends to be reduced in comparison to the alkaline ions, since they function as bridges connecting two oxygens [2] and because of the higher modifier cation field strength, which improves their ability to stabilize the charge in the tetrahedral configuration $[18,19]$. Therefore, alkaline oxides have the most significant flux effect. These data were compatible with the results presented in Fig. 4, where it can be seen that E20 reached $0.5 \%$ water absorption at the lowest temperature, $1170{ }^{\circ} \mathrm{C}$. It is worth mentioning that this temperature coincided with the temperature of maximum densification, above which there was the overfiring, indicating, as expected for very energetic 
fluxes, a very short firing temperature range [20, 21]. In accordance with Fluegel's model, the expected behavior of glasses depends on the total composition of the glasses, suggesting that the interaction between the elements also play a key role in viscosity behavior [1]. However, the interaction of the liquid-phase with the crystalline phase during the firing, which generates dynamic changes in the chemical composition of the melt, is not considered by the model and is difficult to predict $[4,6]$.

Although beyond the scope of this study, some other properties of interest were evaluated and the results are presented in Table VI. As can be seen, in comparison with the STD composition, the other properties of W6.5 such as the flexural strength and the coefficient of thermal expansion were not significantly different. However, as expected, the pyroplastic index was considerably higher. In general, the other properties of the composition E20 were considerably poorer than those of the STD composition.

\section{CONCLUSIONS}

Despite all the differences between the fundamentals on which the Fluegel's model is based and the porcelain tile system, the model could be applied with good accuracy to predict the reduction of the firing temperature for a porcelain tile after the addition of the wollastonite flux. For the spodumene flux, the prediction of the model was not so precise, but was useful as a good guideline for an initial theoretical approach. The addition of wollastonite and spodumene as fluxes in the porcelain tile composition was able to reduce the firing temperature, however with more expressive pyroplastic deformation and a very short firing temperature range. The introduction of spodumene had a stronger fluxing action than the wollastonite. The differences in behavior between the two fluxing agents were found in the type of modifying oxides they provided, which may have changed their influence on the viscosity of the liquid-phase.

\section{ACKNOWLEDGMENT}

This study was financed in part by the Coordenação de Aperfeiçoamento de Pessoal de Nível Superior - Brasil (CAPES) - Finance Code 001.

\section{REFERENCES}

[1] A. Fluegel, Glas. Technol. 48, 1 (2007) 13.
[2] J.M.F. Navarro, El vidrio, $3^{\text {rd }}$ ed., CSIC, Madrid (2003).

[3] A. Fluegel, "Viscosity calculation program, model validity limits, inverse information and correlation matrices", http://glassproperties.com/viscosity/.

[4] C. Zanelli, M. Raimondo, G. Guarini, M. Dondi, J. NonCryst. Solids 357, 16-17 (2011) 3251.

[5] W.D. Kingery, H.K. Bowen, D.R. Uhlmann, Introduction to ceramics, $2^{\text {nd }}$ ed., John Wiley Sons, New York (1976).

[6] C. Zanelli, M. Ardit, S. Conte, R. Soldati, G. Cruciani, M. Dondi, in Qualicer Congr. Mund. Calid. Azulejo Pavim. Cerám., Castellón (2018).

[7] H.C.M. Lengler, J. Vicenzi, C.P. Bergmann, Cerâm. Ind. 14, 4 (2009) 14.

[8] V. Bargues, F. Calomarde, A. Orenga, J. García-Ten, M.F. Quereda, A. Mezquita, in Qualicer Congr. Mund. Calid. Azulejo Pavim. Cerám., Castellón (2010).

[9] O. Turkmen, A. Kucuk, S. Akpinar, Ceram. Int. 41, 4 (2015) 5505.

[10] S.R. Bragança, H.C.M. Lengler, C.P. Bergmann, Cerâmica 56, 339 (2010) 291.

[11] E.S.J. García-Ten, in Qualicer Congr. Mund. Calid. Azulejo Pavim. Cerám., Castellón (2000).

[12] D.U. Tulyaganov, S. Agathopoulos, H.R. Fernandes, J.M.F. Ferreira, J. Eur. Ceram. Soc. 26, 7 (2006) 1131.

[13] ISO 13006, "Ceramic tiles - definitions, classification, characteristics and marking", Int. Org. Stand., Geneva (2018).

[14] S. Conte, M. Dondi, M. Ardit, G. Cruciani, C. Zanelli, in Qualicer Congr. Mund. Calid. Azulejo Pavim. Cerám., Castellón (2018).

[15] S. Conte, C. Zanelli, M. Ardit, G. Cruciani, M. Dondi, Materials 11, 12 (2018) 2475.

[16] J. Wang, M. Wu, H. Tang, J. Han, C. Liu, X. Cao, J. Kang, J. Non-Cryst. Solids 509 (2019) 88.

[17] T. Charpentier, N. Ollier, H. Li, J. Non-Cryst. Solids 492 (2018) 115.

[18] X.H. Zhang, Y.L. Yue, H.T. Wu, Mater. Res. Innov. 17, 3 (2013) 212.

[19] L.G. Bäck, S. Ali, S. Karlsson, D. Möncke, E.I. Kamitsos, B. Jonson, Int. J. Appl. Glas. Sci. 10, 3 (2019) 349.

[20] F. Contartesi, F.G. Melchiades, A.O. Boschi, Bol. Soc. Esp. Ceram. V. 58, 2 (2019) 69.

[21] C. Zanelli, E. Domínguez, C. Iglesias, S. Conte, C. Molinari, R. Soldati, G. Guarini, M. Dondi, Bol. Soc. Esp. Ceram. V. 58, 5 (2019) 199.

(Rec. 22/03/2019, Rev. 24/05/2019, Ac. 28/05/2019) 